\title{
Zircon Hf Isotope Mapping for Understanding Crustal Growth and Gold Metallogenesis in the Great Xing'an Range, Northeast China
}

\author{
PINGPING ZHU ${ }^{1}$, WEI TAO ${ }^{2}$ \\ 1 School of the Earth Sciences and Resources, China University of Geoscience, Beijing \\ 100083, China \\ 2 School of Foreign Languages, China University of Geosciences, Wuhan 430074, China
}

The Great Xing'an Range (GXR), located on the east of the Central Asian Orogenic Belt (CAOB or Altaid), is the world's largest site of juvenile crustal formation from the Phanerozoic Eon and also is an ideal orogeny for crustal growth study. This paper analyzes geological, chronological and $\mathrm{Hf}$ isotopic data from magmatic rocks associated with gold mineralization to gain insights into links between the crustal growth and gold metallogeny, and to focus on exploration in the orogeny. 2188 zircon Hf isotope data and 365 zircon $\mathrm{U}-\mathrm{Pb}$ ages published are employed to discuss the relationship between the crustal growth and gold mineralization in the study area. All the isotopic data have been processed by the ordinary Kriging or polynomial griding method. Based on the regional background and dynamic metallogenic conditions, the study has fully explored the relationship between the crustal growth and metallogenic potential of magmatic-related gold deposits in the study area. The results of newly formed continental crust accounting for $39.7 \%$ (TDMC $<0.8 \mathrm{Ga}$ ), juvenile crust accounting for $40.9 \%$ $(0.8 \mathrm{Ga}<\mathrm{TDMC}<1.1 \mathrm{Ga})$ and the reworking old crust (TDMC $>1.1 \mathrm{Ga}$ ) making up $19.4 \%$ imply that the growth rate of crust is $39.7 \%$ in Phanerozoic. This study indicates that recycling crust plunged into the mantle rapidly in the Phanerozoic. Zircon Hf isotope mapping also shows the spatial relationship between crustal structure and gold mineralization. The location of the gold deposit has a strong link with the low $\varepsilon \mathrm{Hf}(\mathrm{t})$ value, which originates from the old crust. Tectonic regime transition and $\mathrm{Au}-$ bearing magmatic rocks with $\varepsilon \mathrm{Hf}(\mathrm{t})$ bounding from -0.4 to +3.2 are beneficial to magmatic-related gold mineralization. This study suggests that potential target areas for magmatic gold deposits are located around Mohe, the south line of Balinzuoqi-Suyouqi in the GXR. 